International Journal of Current Advanced Research

ISSN: O: 2319-6475, ISSN: P: 2319 - 6505, Impact Factor: SJIF: 5.995

Available Online at www.journalijcar.org

Volume 6; Issue 3; March 2017; Page No. 2815-2818

DOI: http://dx.doi.org/10.24327/ijcar.2017.2818.0114

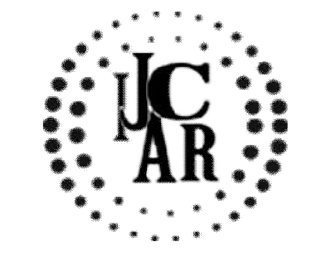

Research Article

\title{
AWARENESS OF BP AMONG OUTPATIENTS
}

\section{Hena Mariam Fathima and Gowri Sethu}

Saveetha Dental College, Saveetha University, Chennai-600077

\section{A R T I C L E I N F O}

\section{Article History:}

Received $18^{\text {th }}$ December, 2016

Received in revised form $16^{\text {th }}$ January, 2017

Accepted $26^{\text {th }}$ February, 2017

Published online $28^{\text {th }}$ March, 2017

\section{Key words:}

Blood pressure, hypertension \begin{abstract}
A B S T R A C T
Topic: Awareness of high blood pressure among out patients

Aim: To establish awareness amongst out patients about high blood pressure

Objective: To conduct a survey to understand the knowledge among out patients regarding high blood pressure and educate them regarding complications and treatment

Background: Blood pressure is the pressure of the blood against the walls of the arteries. High blood pressure is a common disease in which blood flows through arteries at higher than normal pressure. High blood pressure is one of the most crucial health problems and the most common chronic disease in developed and underdeveloped countries. It is called the silent killer which is usually diagnosed incidentally. Although it is a preventable and treatable condition but without treatment it leads to serious and life threatening complications such as heart, kidney and brain disorders.
\end{abstract}

Copyright $₫ 2017$ Hena Mariam Fathima and Gowri Sethu. This is an open access article distributed under the Creative Commons Attribution License, which permits unrestricted use, distribution, and reproduction in any medium, provided the original work is properly cited.

\section{INTRODUCTION}

Blood pressure is the pressure exerted on the walls of the arteries during ventricular systole and diastole which is affected by factors such as cardiac output, blood vessel elasticity, volume, velocity, viscosity of the blood and peripheral resistance ${ }^{[1]}$. Essential hypertension accounts for 90 to $95 \%$ of all types hypertension. There are many risk factors for essential hypertension such as advance in age, sex and family history of hypertension, obesity, atherosclerosis ${ }^{[2]}$. Centre for Disease Control and Prevention 2013, has stated that hypertension is a widespread health problem and is called the "silent killer" because it often has no warning signs or symptoms, and many people don't realize they have it ${ }^{[3]}$. Hypertension is a major contributing factorfor cardiovascular diseases and it may lead to many complications such as stroke, retinopathy, coronary artery disease and renal failure ${ }^{[4]}$.In this modern world, stress is increasing in everyone's life which is also a major contributing factor for hypertension. Hypertension can be treated by pharmacological and nonpharmacological methods. Pharmacological methods involve use of antihypertensive drugs and nonpharmacological intervention includes salt restriction, dietary modification, fat restriction, avoidance of caffeine, smoking and alcohol, yoga, exercise and relaxation technique [2], [4]. Family history is an important non-modifiable risk factor for hypertension. The hereditary nature of hypertension

\section{*Corresponding author: Hena Mariam Fathima}

Saveetha Dental College, Saveetha University, Chennai600077 is well established by numerous family studies [5], demonstrating associations of blood pressure among siblings and between parents and children ${ }^{[6]}$. About $30 \%$ of the blood pressure variance can be attributed to genetic factors ${ }^{[7]}$, and was found to vary from $25 \%$ in pedigree studies to $65 \%$ in twin studies ${ }^{[6]}$. Among various mechanisms proposed to explain the relation between hypertension and positive family history of hypertension, are the increased renal proximal sodium reabsorption ${ }^{[8]}$, genetic traits related to high blood pressure such as high sodium-lithium counter-transport, low urinary kallikrein excretion, elevated uric acid level, high fasting plasma insulin concentrations, high-density LDL subfractions, fat pattern index, oxidative stress and body mass index, as well as shared environmental factors such as sodium intake and heavy metal exposure ${ }^{[9-12]}$.

Stress is an important factor which causes blood pressure ${ }^{[13]}$.Excess dietary sodium predisposes to high $\mathrm{BP}^{[14,15]}$. Approximately $90 \%$ of individuals with prehypertension have at least one other cardiovascular risk factor and $68 \%$ have at least one significant clinical risk factor for heart disease or stroke [16]. Some studies have demonstrated that prehypertension is an independent risk factor for cardiovascular disease (CVD) ${ }^{[17,18,19,20]}$.

\section{MATERIALS AND METHODS}

The sample size of this study was 100 outpatients. This was a questionnaire based study. The questionnaire comprised of 15 questions relating to blood pressure. It covered factors like age, sex and so on. It also covered factors like stress, salt uptake, medication and basic knowledge of blood pressure. 
Sex factors are male and female. A general survey was taken through a standardised questionnaire distributed to 100 people.

DO YOU KNOW WHAT BP IS?

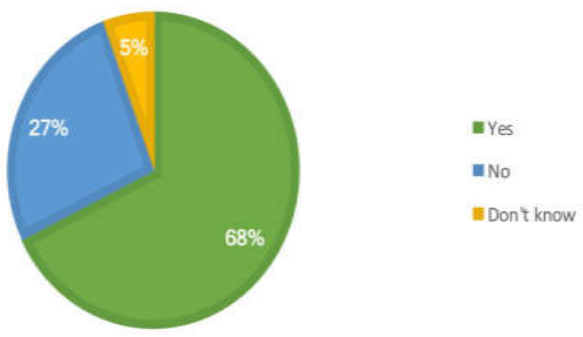

CAN STRESS LEAD TO INCREASE IN BP

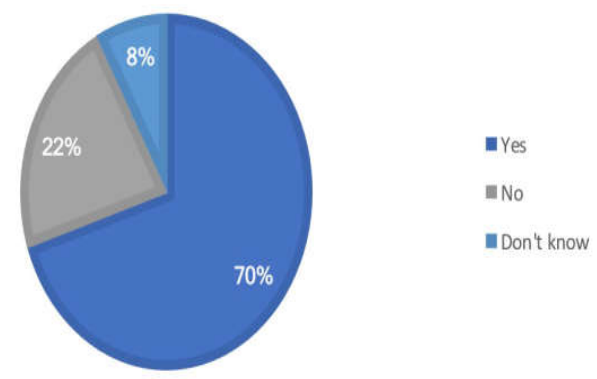

CAN HEART DISEASE BE CAUSED BY BP?

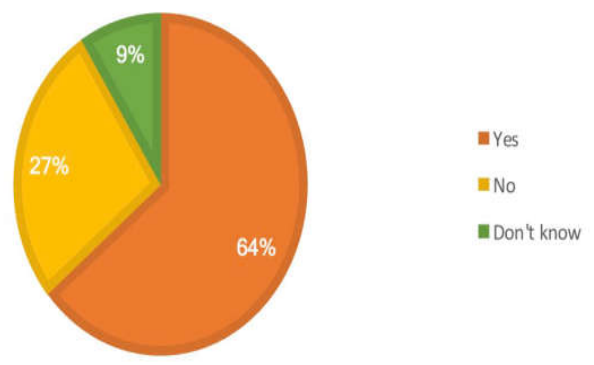

SHOULD MEDICATION FOR BP SHOULD BE TAKEN LIFE LONG?

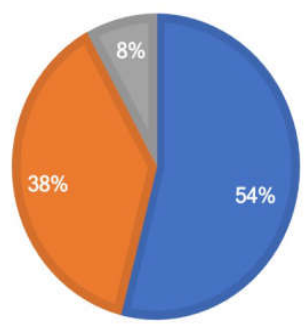

wes

mo

Don't know

\section{RESULTS AND DISCUSSION}

$68 \%$ of the sample knew what BP stood for and knew that it is the pressure in the arteries while $27 \%$ were not aware of such a thing. $5 \%$ had heard the term quite frequently but didn't know what it was exactly. Majority of the sample have knowledge about BP but there is not enough awareness about the same.The prevalence of hypertension is higher in those with a family history of hypertension at all levels (parents, grandparents, siblings and children) than those without a family history ${ }^{[21]}$

$70 \%$ of the test group believed that stress can increase blood pressure. This stress can be of many types since many different age groups were seen. The stress can be of academics among the younger population, work pressure and family pressure among the older population. $22 \%$ of the population did not think that stress can lead to an increase in the blood pressure and thought of them both are completely independent variables. Stress can cause hypertension through repeated blood pressure elevations as well as by prolonged exposure to vasoconstricting hormones that increase blood pressure. Factors affecting blood pressure through stress include job strain, race, social environment, and emotional distress. Overall, studies show that stress does not directly cause hypertension, but can have an effect on its development. $^{[22]}$

$64 \%$ believes that heart disease can be caused by blood pressure but they could not explain the relationship between blood pressure and heart disease. $27 \%$ was unaware about the correlation of blood pressure with heart disease. They believe that there is no relation between blood pressure and heart diseases and mainly thought of diet and lifestyle as the reasons for heart disease. The physical impact of high BP can cause endothelial injury. Injured endothelium results in impairment in the synthesis and the release of the potent vasodilator-nitric oxide and also promotes the accumulation of reactive oxygen species and other inflammatory factors which mediate the development of atherosclerosis, thrombosis, and vascular occlusion. This inflammatory process is a prominent feature in the pathogenesis of both hypertension and atherosclerosis ${ }^{[23]}$. Nitric oxide stimulates guanylyl cyclase to form 3',5'-cyclic guanosine monophosphate, which results in vasodilatation of vascular smooth muscle cells, prevention of platelet adhesion and aggregation, and exertion of anti-inflammatory, antiproliferative, and antimigratory effects on leukocytes, endothelial cells, and vascular smooth muscle cells, thus providing protection from atherosclerosis. Attenuated nitrogen oxide bioavailability, the main characteristic of endothelial dysfunction, is present in arterial hypertension $[24,25,26]$

Hypertension by itself can cause myocardial ischemia in the absence of coronary heart disease (CHD). Increased afterload due to hypertension can result in significant left ventricular hypertrophy $(\mathrm{LVH})$, which may impair ventricular relaxation and compromise coronary blood flow during diastole. Although genetic factors have been associated with LVH, chronic uncontrolled hypertension appears to be the major cause ${ }^{[27,28]}$

Only 54\% knows that if a person is suffering from high blood pressure, the medication for it must be taken throughout the individual's life. $38 \%$ of the population didn't think it was necessary for a person suffering from high blood pressure to take the medication throughout their life. They believed that once the blood pressure was brought back to normal the 
medication can be stopped. This is a false notion. This is because once the medication stops, the blood pressure can shoot back up or even higher than before and this fluctuation can be very dangerous.

\section{CONCLUSION}

Blood pressure is a very common disorder and if it is controlled, life span and quality of life can be improved greatly. It can be seen that knowledge about blood pressure and the various factors contributing to it and its effects is moderate but not enough. Only a little more than half the population know about blood pressure. The lack of awareness can be quite dangerous in the future for the individuals. Individuals with high blood pressure can reduce it by taking medication but they can also make lifestyle changes like dietary changes, taking part in physical activity and exercising. Since mild to moderate hypertension is asymptomatic, everyone over 40 yrsshould check their blood pressure regularly because the sooner hypertension is detected and treated, the better.

This survey is done to create awareness among the society that prevention is better than cure when it comes to blood pressure. Therefore a small awareness will lead to a great health benefit among the growing population.

\section{References}

1. Brunner \& Suddarth's. Text book of Medical Surgical Nursing. Janice L.Hinkle, Kerry H.Cheever editors 12th ed. Philadelphia. Wolter Kluwer company. 2014;684-9.

2. Joyce M. Black, Jane Hokanson Hawks. Medical Surgical Nursing: Clinical Management for Positive Outcomes. Philadelphia: W.B. Saunderscompany.7th ed. 2001;p.1387- 1404 .

3. High Blood Pressure (Hypertension) Information | cdc.gov.[internet]; 2016, September 13.

4. Lewis, Heitkemper Dirksen, O’Brien, Bucher. Medical surgical Nursing: Assessment and Management of clinical problems. Maureen Barry, Sandra Goldsworthy, Donna Goodridge editors. 4th ed. Canada. Elsevier publication.2013. p.779- 795.

5. Barlassina C, Lanzani C, Manunta P, Bianchi G. Genetics of essential hypertension: from families to genes. J Am Soc Nephrol: JASN. 2002;13 Suppl 3:S155-64.

6. Carretero OA, Oparil S. Essential hypertension. Part I: definition and etiology. Circulation. 2000;101(3):32935 .

7. Corvol P, Jeunemaitre X, Charru A, Soubrier F. Can the genetic factors influence the treatment of systemic hypertension? The case of the renin-angiotensinaldosterone system. Am J Cardiol. 1992;70(12):14D$20 \mathrm{D}$.

8. Simsolo RB, Romo MM, Rabinovich L, Bonanno M, Grunfeld B. Family history of essential hypertension versus obesity as risk factors for hypertension in adolescents. Am J Hypertens. 1999;12(3):260-3.

9. Williams RR, Hunt SC, Hopkins PN, Hasstedt SJ, Wu LL, Lalouel JM. Tabulations and expectations regarding the genetics of human hypertension. Kidney Int Suppl. 1994;44:S57-64.
10. Siervogel RM. Genetic and familial factors in essential hypertension and related traits. Am J Phys Anthropol. 1983;26(S1):37-93.

11. Feig DI, Kang DH, Johnson RJ. Uric acid and cardiovascular risk. $N$ Engl J Med. 2008;359(17):181121.

12. Munzel T, Gori T, Bruno RM, Taddei S. Is oxidative stress a therapeutic target in cardiovascular disease? Eur Heart J. 2010;31(22):2741-8.

13. Vrijkotte, T. G. M., L. J. P. Van Doornen, and E. J. C. De Geus. "Effects of Work Stress on Ambulatory Blood Pressure, Heart Rate, and Heart Rate Variability." Hypertension 35.

14. Meneton P, Jeunemaitre X, de Wardener HE, MacGregor GA. Links between dietary salt intake, renal salt handling, blood pressure, and cardiovascular diseases. Physiol Rev. 2005;85:679-715.

15. He FJ, MacGregor GA. Salt, blood pressure andcardiovascular disease. Curr Opin Cardiol. 2007;22:298-305.

16. Greenlund KJ, Croft JB, Mensah GA: Prevalence of heart disease and stroke risk factors in persons with prehypertension in the United States, 1999-2000. Arch Intern Med. 2004, 164: 2113-2118. 10.1001/archinte.164.19.2113.

17. Vasan RS, Larson MG, Leip EP, Evans JC, O’Donnell CJ, Kannel WB, Levy D: Impact of high-normal blood pressure on the risk of cardiovascular disease. N Engl J Med. 2001, 345: 1291-1297. 10.1056/NEJMoa003417.

18. Wu G, Wu Z, Liu J, Wang W, Zhao D, Ceng Z, Wang W, Liu J, Qin L, Liu S: Impact of high-normal blood pressure on risk of cardiocerebrovascular disease in 11 provinces in China. Zhonghua Yi Xue Za Zhi. 2002, 82: 1083-1085.

19. Liszka HA, Mainous AR, King DE, Everett CJ, Egan BM: Prehypertension and cardiovascular morbidity. Ann Fam Med. 2005, 3: 294-299. 10.1370/afm.312.

20. Qureshi AI, Suri MF, Kirmani JF, Divani AA, Mohammad Y: Is prehypertension a risk factor for cardiovascular diseases?. Stroke. 2005, 36: 1859-1863. 10.1161/01.STR.0000177495.45580.f1.

21. Priyanga Ranasinghe, Dilini N. Cooray, Ranil Jayawar dena and Prasad Katulanda BMC Public Health201515:576: 10.1186/s12889-015-1927-7

22. Kulkarni S, O'Farrell I, Erasi M, Kochar MS Medical College of Wisconsin, Milwaukee, USA.1998 Dec;97(11):34-8.

23. Oparil S, Zaman MA, Calhoun DA. Pathogenesis of hypertension. Annals of Internal Medicine. 2003;139 (9):761-776.

24. Brunner H, Cockcroft JR, Deanfield J, et al., on behalf of the Working Group on Endothelins and the Endothelial Factors of the European Society of Hypertension. Endothelial function and dysfunction. Part II: association with cardiovascular risk factors and diseases. A statement by the Working Group on Endothelins and Endothelial Factors of the European Society of Hypertension. J Hypertens. 2005; 23:233246.

25. Lüscher TF, Vanhoutte PM. Endothelium-dependent contractions to acetylcholine in the aorta of the spontaneously hypertensive rat. Hypertension. 1986; 8:344-348. 
26. Panza JA, Quyyumi AA, Brush JE Jr, et al. Abnormal endothelium-dependent vascular relaxation in patients with essential hypertension. $N$ Engl J Med. 1990; 323:22-27.

27. Levy D, Anderson KM, Savage DD, Kannel WB, Christiansen JC, Castelli WP. Echocardiographically detected left ventricular hypertrophy: prevalence and risk factors. The Framingham heart study. Annals of Internal Medicine. 1988; 108(1):7-13.
28. Rheeder P, Stolk RP, Mosterd A, Pols HAP, Hofman A, Grobbee DE. Insulin resistance syndrome and left ventricular mass in an elderly population (the Rotterdam study) American Journal Cardiology. 1999; 84(2):233-236.

\section{Please cite this article in press as:}

Hena Mariam Fathima and Gowri Sethu (2017), 'Awareness Of Bp Among Outpatients', International Journal of Current Advanced Research, 6(3), pp. 2815-2818. http://dx.doi.org/10.24327/ijcar.2017.2818.0114 